\title{
SIMULTANEOUS TREATMENT WITH OIL HEAT AND DENSIFICATION ON PHYSICAL PROPERTIES OF Populus $\times$ Canadensis WOOD
}

\author{
Antonio Villasante ${ }^{1,4}$ \\ Santiago Vignote ${ }^{2}$ \\ Alvaro Fernandez-Serrano ${ }^{1}$
}

Rubén Laina ${ }^{2}$

\begin{abstract}
Samples of wood from Populus $\times$ canadensis $(9,5 \%$ moisture $)$ were treated with olive oil at $195{ }^{\circ} \mathrm{C}$ simultaneously with $15 \%$ or $30 \%$ compression densification, and the results were compared with samples subjected to oil heat treatment without densification, and control samples. The density of the treated samples increased by $18 \%, 43 \%$ and 1,5\% respectively, and barely changed over the six subsequent months stored inside the laboratory room (at approximately $65 \% \mathrm{RH}, 20^{\circ} \mathrm{C}$ ). This was due to the fact that the slight weight increment caused by the additional moisture content was offset by the increase in volume from the springback effect. When subjected to atmospheres with different relative humidities, the treated samples stabilised at the same time as the control samples, although the treated samples had a significantly lower moisture absorption than the control samples. It was also observed that the hygroscopic shrinkage in oil heat densification treatment samples was approximately half those of the control samples. The initial densification was partially lost as a result of springback: approximately $3 \%$ in the first springback at a relative humidity of $65 \% \mathrm{RH}$, and an additional $4 \%$ in the second springback to a relative humidity of $85 \% \mathrm{RH}$. Once this latter relative humidity had been attained, no new losses in densification were observed. The ageing of the oil used in the treatment caused a slight loss of densification in the densest samples.
\end{abstract}

Keywords: Age of the oil, compression-set, olive oil, springback, wood density.

\section{INTRODUCTION}

Wood is a renewable material that offers undoubted advantages but also has its drawbacks. Various researchers have developed techniques for modifying wood to avoid or reduce its unfavourable properties. The objective of modified woods is to improve certain properties, for example, by increasing its dimensional stability, resistance to bases, acids and ultraviolet radiation and decreasing biodeterioration and hygroscopicity, or improving its mechanical performance (Forest Products Laboratory 2010).

One of the modification techniques is heat treatment, which consists of maintaining the wood at high temperatures for some hours (Kamke 2006, Kutnar and Sernek 2007, Forest Products Laboratory 2010). In Finnish ThermoWood and PLATO wood the treatment occurs by heating the air around the wood, while in rectification wood the process is carried out in an atmosphere with a high nitrogen content and less than $2 \%$ oxygen (Rapp 2001). In oil heat treatment (OHT), the oxygen is separated from the wood by immersion in hot oil (Dubey et al. 2012b). The OHT samples presented a significant reduction in equilibrium moisture content and water ab- 
sorption compared to the untreated samples (Bak and Nemeth 2012, Lee et al. 2018). Bak and Nemeth (2012) reported that water absorption is not blocked in samples treated with OHT, but merely reduced as it decreases the amount of places where the water can connect. This reduction is due to the lower number of hydroxyl groups in which the water can bind and to the increased crosslinking in the lignin (Lee et al. 2018). Equilibrium moisture is achieved at the same time in the OHT and the untreated samples (Bak and Nemeth 2012).

The shrinkage in the wood also improve with the OHT content. Dubey et al. (2012a) observed that this treatment causes a reduction in the volumetric swelling percentage and increases anti-swelling efficiency (ASE). The improvement in the dimensional stability of the wood is greater when the oil temperature and treatment time increases (Bak and Nemeth 2012). Rapp (2001) also observed a higher ASE in the samples treated at higher temperatures. Bak and Nemeth (2012) reported that in OHT wood treated with three vegetable oils the increase in ASE was greater in the tangential direction then in the radial direction. Although the anisotropy of the wood decreased, it is not completely removed. Okon et al. (2018) also observed greater reductions in shrinkage in the tangential than in the radial direction in wood treated with silicone oil as a heating medium.

One factor that can affect the OHT treatment is the type of oil used. The most commonly used oils are of vegetable origin. Some studies reported differences in the results based on the type of oil. Wang and Cooper (2005) found that palm oil was more effective than soybean oil for achieving dimensional stability. Lyon et al. (2007) considered that the most important characteristic of the oil is its unsaturation degree. Oils with a higher proportion of polyunsaturated fatty acids are more recommended for OHT treatments. Tomak et al. (2011) reached the same conclusion and used iodine values in their work to establish the unsaturation degree. However, studies by other authors observed no significant differences in equilibrium moisture or moisture absorption between OHT samples treated with sunflower oil, linseed oil and rapeseed oil (Bak and Nemeth 2012). Dubey et al. (2011) observed less moisture absorption in OHT samples treated with fresh oil than in samples treated with pre-heated oil, although there were no significant differences in volumetric swelling. In that work, the authors justified these differences as being due to the evaporation of volatile compounds and the heat polymerization of the oil.

Another common type of modification of the wood is densification, developed since the early 20th century (Kollmann et al. 1975). Densification consists of increasing density by applying pressure to the previously heated wood in such a way that the lumens partially collapse (Song et al. 2018). Wood is usually heated by means of liquid water or steam. Some authors have used other fluids, as in the case of Song et al. (2018), who successfully applied densification in a solution of $\mathrm{NaOH}$ and $\mathrm{Na}_{2} \mathrm{SO}_{3}$ in their work. Densification is a technique that is particularly suited to low-density woods (Kamke 2006), because it enables them to be used for purposes where high density woods would normally be chosen (Kutnar and Sernek 2007). Kawai et al. (1992) indicated that during densification the cellulose crystals become reoriented, the hemicelluloses are partially hydrolysed and the lignin is partially degraded. The main application of densification is to increase the mechanical properties of the wood (Welzbacher et al. 2008, Gašparík et al. 2016, Laskowska 2020). Kutnar et al. (2008) obtained increases in MOE and MOR of between $35 \%$ and $100 \%$, depending on the degree of densification. Sotomayor (2016) reported twice the MOE in densified wood than in the control samples. Kamke (2006) obtained MOE values in densified wood that were three times greater than in the control samples. It is important to highlight that the effect of densification may be reversible when the moisture content in the wood increases (Kamke 2006, Welzbacher et al. 2008), a phenomenon known as springback, or recovery from compression. This occurs when the internal stresses that appear in the densification are relaxed, and part of the wood's internal structure seeks to recover its original form (Morsing 1998). Springback is reduced through several mechanisms: by making the cell wall inaccessible to water, forming crosslinks between the wood components in the deformed state, and releasing stresses in the microfibrils during compression (Morsing 1998). Welzbacher et al. (2008) found that springback depends more on the temperature of the treatment then on the duration of the compression, and reported a particularly significant effect at temperatures over $180{ }^{\circ} \mathrm{C}$.

To combine favourable effects, some researchers have analysed the behaviour of wood subjected to densification and subsequently to OHT. Fang et al. (2011) observed that in wood treated in this way the equilibrium moisture and the springback were reduced, and this reduction was greater in the samples treated with OHT at higher temperatures. Hsu et al. (1988) and Laborie (2006) indicated that in this combined treatment there was a joint occurrence of a reversible swelling due to the hygroscopicity of the wood and another irreversible swelling due to the compression-set recovery. Fang et al. (2011) quantified the incidence of the irreversible swelling by performing saturation tests on the samples, and observed that it decreased as the time and the treatment temperature increased.

In spite of the advantages obtained by performing the densification of the wood in combination with the 
OHT treatment, no works were found in which these two processes are carried out simultaneously to benefit of the heating caused by the oil treatment for wood densification. The aim of the present work was to establish the behaviour in regard to moisture content in low density wood of Populus $\times$ canadensis when the densification and OHT are carried out simultaneously.

\section{MATERIAL AND METHODS}

\section{Samples preparation}

Ten logs were used from the I-214 clone of Populus $\times$ canadensis Moench, measuring $0,35 \mathrm{~m}$ long and with a diameter of $0,2 \mathrm{~m}$ to $0,3 \mathrm{~m}$. They were obtained from a wooden fruit packaging company that uses trees from the Ebro Valley (Spain). Each log was identified with a letter (from A to J) to control the log factor. The largest possible quantity of strips with cross-sectional dimensions of $22 \mathrm{~mm}$ x $22 \mathrm{~mm}$ and $350 \mathrm{~mm}$ long was extracted from each log, with the rings parallel to the transversal edges. The strips were stored inside the laboratory until the samples attained a moisture content of near $12 \%$. They were subsequently processed with a thickness planer until they had a final section of $20 \mathrm{~mm}$ x $20 \mathrm{~mm}$, when they were stored for another 15 days. Immediately before treatment, each $350 \mathrm{~mm}$ strip was cut transversally to obtain a sample of $275 \mathrm{~mm}$ in length, and a moisture sample of $70 \mathrm{~mm}$ which was only used to estimate the moisture content of the probe (Figure 1).

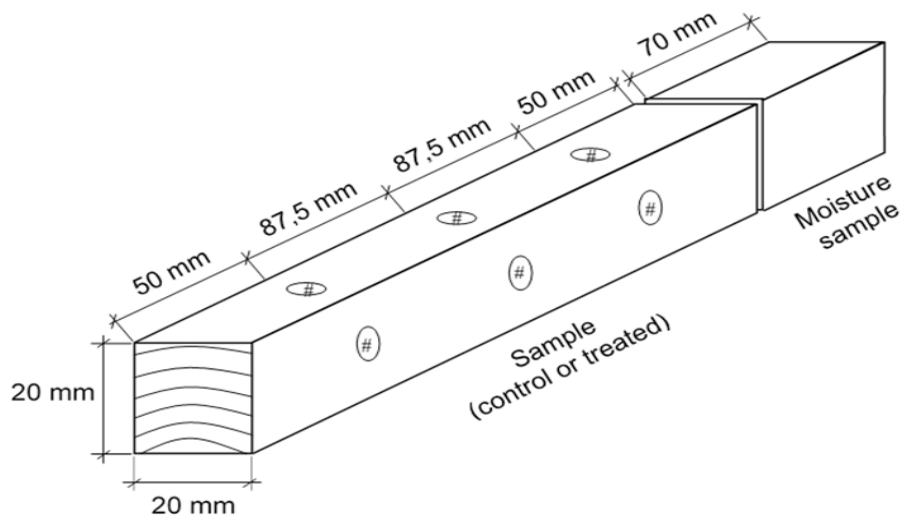

Figure 1: Sample preparation.

\section{OHDT and OHT treatments}

Four samples were randomly selected from each of the ten logs, one for each treatment type. The following treatments were performed: thickness.

$\mathrm{OHDT}_{\mathrm{h}}$ : OHT treatment simultaneously with high densification, with an approximate $6 \mathrm{~mm}$ reduction in

OHDT $_{1}$ : OHT treatment simultaneously with low densification, with an approximate $3 \mathrm{~mm}$ reduction in thickness.

OHT: treatment in hot oil (without densification).

Control: samples without densification and without OHT.

The main samples of $275 \mathrm{~mm}$ were measured lengthwise with a $1 \mathrm{~mm}$ precision measuring tape and crosswise with a $0,01 \mathrm{~mm}$ precision micrometer. Both the radial and tangential crosswise measures of the samples were taken in three measurement points: two at $50 \mathrm{~mm}$ from the ends and one in the centre (Figure 1). Each 
measurement point was marked by circling the zone of contact of the micrometer with a pencil to be able to repeat the measures at exactly the same point. The sample was weighed on a $0,01 \mathrm{~g}$ precision scale.

The oil used in the treatment was virgin olive oil from Aceites Toledo S.A. (Los Yébenes, Spain). Fullana et al. (2004) indicated a smoke point of $210^{\circ} \mathrm{C}$ for this type of oil, whereas Li et al. (2016) indicated a range between $205^{\circ} \mathrm{C}$ and $215{ }^{\circ} \mathrm{C}$. It was decided to use a temperature of $195{ }^{\circ} \mathrm{C} \pm 4{ }^{\circ} \mathrm{C}$ in order not to reach the smoke point, which could lead to the premature degradation of the oil. The treatment was performed in a Nevir NVR-6522F fryer, and the temperature was checked with a Digiflex TP101 digital thermometer.

The densification of each sample was carried out individually, with a press formed by two steel plates with a thickness of $8 \mathrm{~mm}$ and $283 \mathrm{~mm}$ in length, joined with eight M10 cap screws (four each side of the probe). The time required for the interior of the sample to attain a temperature of $190{ }^{\circ} \mathrm{C}$ was calculated using MacLean's formula, based on Fourier' differential equation (Kollmann 1959). For the section of the samples of $20 \mathrm{~mm} x$ $20 \mathrm{~mm}$, the estimated time was two minutes. To maintain a minimum temperature of $190{ }^{\circ} \mathrm{C}$ at all points of the sample for 60 minutes, a preheating phase was implemented, submerging the sample in oil at $195{ }^{\circ} \mathrm{C}$ for 62 minutes. In this phase the sample was loosely attached to the outside of the steel press with a steel wire with a section of $0,3 \mathrm{~mm}$ to prevent it from floating, and ensure that the oil was in contact with the entire surface of the wood. When the sample was introduced in the oil, an intense bubbling was observed caused by the expulsion of air and moisture from the interior of the wood. At the end of the preheating phase, the initial bubbling ceased.

After the preheating phase, the compression was performed by placing the sample between the two plates of the press, centring it between the two rows of cap screws. The plates were closed without tightening the cap screws, simply by adjusting the discs to the sample, and it was once again submerged in the oil. The press was removed from the hot oil every 15 minutes and each cap screw was tightened a quarter turn, four times (to avoid imbalances in the plates). The quarter-turn tightening sequence is similar to the one used in cylinder heads in combustion engines. In each extraction of the hot oil, the samples were tightened approximately 1,5 $\mathrm{mm}$ and it took one minute to become re-immersed in the hot oil. The compression was done in a radial direction to achieve plastic yielding and the gradual collapse of the wood cells (Reiterer and Stanzl-Tschegg 2001), locating the tangential faces of the sample in contact with the plates of the press.

In the $\mathrm{OHDT}_{1}$ treatment the plates were tightened twice, so a final densified thickness of approximately $17 \mathrm{~mm}$ was estimated (a decrease of $3 \mathrm{~mm}$ due to two tightenings of $1,5 \mathrm{~mm}$ each). The treatment time of the $\mathrm{OHDT}_{1}$ samples was 92 minutes (62 minutes of preheating and two of heating before tightening periods of 15 minutes each).

In the $\mathrm{OHDT}_{\mathrm{h}}$ treatment the plates were tightened four times, so a final densified thickness of approximately $14 \mathrm{~mm}$ was estimated (decrease of $6 \mathrm{~mm}$ due to four tightenings of $1,5 \mathrm{~mm}$ each). The treatment time of the $\mathrm{OHDT}_{\mathrm{h}}$ samples was 122 minutes (62 minutes of preheating and four of heating before tightening periods of 15 minutes each).

\section{Conditioning of samples}

After the treatment, the samples were left to cool outside the oil and in the press for 20 hours. Once this time had elapsed, the samples were removed from the press, the radial dimensions were measured in the three measurement points, and they were weighed again. The treated samples and the control samples were stored inside the laboratory. The OHT and OHDT samples were treated simultaneously over three months. Once the treatment was finalised, all the samples were preconditioned for 15 days in a conditioning chamber at $65 \% \mathrm{RH}$ and $20^{\circ} \mathrm{C}$ and subsequently stored for five months, grouping the ten samples of each treatment type in a plastic bag. The response to moisture content was analysed in five stable environmental conditions (SEC), alternating relative humidities $65 \%, 85 \%, 65 \%, 85 \%$, and $65 \%$ (SEC to $\mathrm{SEC}_{5}$, respectively), all at $20{ }^{\circ} \mathrm{C}$. At the start and end of each SEC the samples were weighed and measured in each measurement point. In the first four days of each SEC the samples were weighed every day, and on subsequent days the samples were weighed every four days. The moisture content of the wood was considered to be stable when the difference in weight taken four days apart was less than $0,2 \%$.

As the samples were not oven-dried in any part of the process, the moisture content of the samples was estimated from the $70 \mathrm{~mm}$ long moisture sample (Figure 1). The moisture content of the moisture samples was obtained from the difference in weights before and after oven drying at $103{ }^{\circ} \mathrm{C}$, following EN 13183-1:2002 (2002). Based on this moisture, the oven dry mass $\left(\mathrm{m}_{0}\right)$ of the treated and control samples was estimated using Equation 1. 


$$
\mathrm{m}_{0}=\frac{\mathrm{m}_{\mathrm{at}}}{1+\frac{\grave{\mathrm{u}}_{\mathrm{MS}}}{100}} \times 100
$$

Where $\mathrm{m}_{\mathrm{at}}$ is the mass of the sample before starting treatment and $\omega_{\mathrm{MS}}($ in $\%)$ is the moisture content obtained from the $70 \mathrm{~mm}$ long moisture sample (Figure 1).

From the mass of each sample $\left(\mathrm{m}_{\mathrm{i}}\right)$ in a SEC and from the estimation of its $\mathrm{m}_{0}$, the percentage of total sorption of oil and water $\left(\mathrm{TS}_{\mathrm{ow}}\right.$, in \%) can be obtained by means of Equation 2. In the case of control samples, $\mathrm{TS}_{\mathrm{ow}}$ corresponds exclusively to water and is therefore equivalent to moisture content. In the samples treated with oil $\left(\mathrm{OHDT}_{\mathrm{h}}, \mathrm{OHDT}_{1}\right.$, and $\left.\mathrm{OHT}\right), \mathrm{TS}_{\mathrm{ow}}$ corresponds to a combination of water and oil.

$$
\mathrm{TS}_{\mathrm{ow}}=\frac{\mathrm{m}_{\mathrm{i}}-\mathrm{m}_{0}}{\mathrm{~m}_{0}} \times 100
$$

Similarly, the partial sorption of water ( $\mathrm{PS}_{\mathrm{w}}$, in \%) was calculated by means of Equation 3 . This indicates the change in the mass of water that occurs between the start of a $\operatorname{SEC}_{i}\left(\mathrm{~m}_{\mathrm{i}}\right)$ and the end $\left(\mathrm{m}_{\mathrm{i}+1}\right)$.

$$
\mathrm{PS}_{\mathrm{w}}=\frac{\mathrm{m}_{\mathrm{i}+1}-\mathrm{m}_{\mathrm{i}}}{\mathrm{m}_{\mathrm{i}}} \times 100
$$

To determine the recovery of form in the compressed samples, Fang et al. (2011) used the compression-set recovery variable. This was obtained by measuring the samples in oven-dry moisture content. In the present study, the compression-set recovery was not calculated because the aim was to simulate the behaviour of wood in natural conditions, and artificial oven-drying could produce irreversible alterations. This was also the reason that the anti-swelling efficiency was not used (Forest Products Laboratory 2010). The intensity of the densification of the samples was estimated by means of compression set (Welzbacher et al. 2008, Wehsener et al. 2018) according to Equation 4.

$$
\mathrm{CS}=\frac{\mathrm{R}_{\mathrm{bt}}-\mathrm{R}_{\mathrm{SEC}_{i}}}{\mathrm{R}_{\mathrm{bt}}} \times 100
$$

Where CS is compression set (\%), and $\mathrm{R}_{b t}$ and $\mathrm{R}_{\mathrm{SECi}}$ are the mean of the radial dimensions in the three measurement points before treatment and after the $\mathrm{SEC}_{\mathrm{i}}$ stage respectively.

\section{Statistical analysis}

The differences between the groups were analysed by ANOVA, followed by Tukey's post hoc test. The densities of the samples before treatment, after treatment and before $\mathrm{SEC}_{1}$ were compared by means of the paired samples T-Test. Linear regression was used to establish the influence of the age of the oil on the shrinkage. The statistical analysis was performed with the R program, version 3.6.1 (R Core Team 2019) with a significance level of 0,05 . 


\section{RESULTS AND DISCUSSION}

The treated samples darkened as a result of the treatment, and this change was maintained throughout the entire SEC. This effect coincides with the results of Dubey et al. (2011) in samples of Pinus radiata treated with linseed oil. Lee et al. (2018) justified the change in colour as being due to the formation of an oil layer on the wood surface and the caramelisation of soluble sugars produced from hydrolysed hemicellulose during heat treatment.

The densities of the samples according to the type of treatment are shown in Table 1 . The mean density before treatment was $0,456 \mathrm{~g} / \mathrm{cm}^{3}$ (with $9,6 \%$ moisture content), coinciding with the interval 0,420 to 0,480 $\mathrm{g} / \mathrm{cm}^{3}$, included in AITIM (1997). Other authors obtained lower densities in their studies (Istok et al. 2016). This difference can be explained by the intrinsic variety in the properties of the wood, and is increased by the diversity of the development techniques that are applied to this species (plantation framework, pruning, watering, fertilisation, etc.).

Table 1: Densities (in $\mathrm{g} / \mathrm{cm}^{3}$ ) before treatment, after treatment and before conditioning. In brackets Coefficient of variation (in \%). The lower part in each case shows the increase in density between stages.

\begin{tabular}{|c|c|c|c|c|}
\hline Density & $\mathrm{OHDT}_{\mathrm{h}}$ & $\mathrm{OHDT}_{1}$ & OHT & control \\
\hline $\begin{array}{c}\text { Moisture content before } \\
\text { treatment }(\%)\end{array}$ & $9,6^{\mathrm{a}}(3,63)$ & $9,6^{\mathrm{a}}(4,51)$ & $9,5^{\mathrm{a}}(6,23)$ & $9,5^{\mathrm{a}}(2,35)$ \\
\hline $\begin{array}{c}\text { Density before } \\
\text { treatment }\end{array}$ & $0,456^{\mathrm{a}}(9,82)$ & $0,450^{\mathrm{a}}(8,70)$ & $0,455^{\mathrm{a}}(6,90)$ & $0,464^{\mathrm{a}}(8,49)$ \\
\hline $\begin{array}{c}\text { Density after treatment } \\
\text { Increase }\left(\mathrm{g} / \mathrm{cm}^{3}\right)\end{array}$ & $\begin{array}{c}0,651^{\mathrm{c}}(7,87) \\
+0,195^{* * *}\end{array}$ & $\begin{array}{c}0,532^{\mathrm{b}}(7,65) \\
+0,082^{* * *}\end{array}$ & $\begin{array}{c}0,462^{\mathrm{a}}(6,80) \\
+0,007 * * *\end{array}$ & $\begin{array}{c}0,463^{\mathrm{a}}(8,51) \\
-0,001^{* * *}\end{array}$ \\
\hline $\begin{array}{c}\text { Density before Stable } \\
\text { Environmental } \\
\text { Condition 1 }\left(\mathrm{SEC}_{1}\right) \\
\text { Increase }\left(\mathrm{g} / \mathrm{cm}^{3}\right)\end{array}$ & $0,647^{\mathrm{c}}(7,54)$ & $0,538^{\mathrm{b}}(7,52)$ & $0,472^{\mathrm{a}}(6,88)$ & $0,463^{\mathrm{a}}(8,43)$ \\
& $-0,004^{* *}$ & $+0,006^{* * *}$ & $+0,010^{* * *}$ & $+0,0005^{*}$ \\
\hline
\end{tabular}

In the control samples, the density changed less than $0,001 \mathrm{~g} / \mathrm{cm}^{3}$ during the six months before treatment and before $\mathrm{SEC}_{1}$. The $\mathrm{OHDT}_{\mathrm{h}}$ treatment caused a significant increase in density of $43 \%$, and an increase of $18 \%$ in $\mathrm{OHDT}_{1}$ as a result of densification. A slight increase in density $(1,5 \%)$ was observed during the OHT treatment (without densification), representing less than $0,001 \mathrm{~g} / \mathrm{cm}^{3}$. In the six months after the treatment, the treated probes underwent slight changes in density. In these months the moisture content only increased from $9,5 \%$ to $12 \%$. There were two overlapping effects in this period, which modified the density of the OHDT samples in opposite ways: on the one hand there was a slight increase in moisture content, which led to an increase in density; and on the other there was a springback effect (Kamke 2006, Kutnar and Sernek 2007) which increased the volume of the wood and therefore decreased its density. The springback was more significant in the $\mathrm{OHDT}_{\mathrm{h}}$ samples, which were more densified. A slight decrease in density was observed in these samples, as indicated by the negative increase detected in the density. In contrast, in the less densified OHDT samples $^{2}$ the effect of the moisture content was slightly greater than the springback, so the density increased slightly.

The changes in the amount of water and oil absorbed are shown in Figure 2. The stabilisation of the moisture content in each SEC of the treated samples and the control samples occurred at the same time, so the decrease in the moisture uptake rate in treated samples can be attributed to the lower water storage capacity (Bak and Nemeth 2012). The TS ${ }_{\text {ow }}$ values corresponding to the control samples showed the usual hygroscopic behaviour for wood. In the control samples it was observed that in the different SECs of $65 \% \mathrm{RH}$, a moisture content of between $11 \%$ and $13 \%$ was found; lower values were obtained when this was achieved from lower relative humidity $\left(\mathrm{SEC}_{1}\right)$ and higher values from higher relative humidities $\left(\mathrm{SEC}_{3}\right.$ and $\left.\mathrm{SEC}_{5}\right)$. This difference in values is explained by sorption hysteresis (Forest Products Laboratory 2010). The treated samples followed parallel behaviours of $\mathrm{TS}_{\text {ow }}$, ordered according to the intensity of the densification. All the treated samples had the same $\mathrm{TS}_{\mathrm{ow}}$ before treatment, and separation occurred during treatment. From this point on the distances 
remained approximately constant. It is worth noting that the values of $\mathrm{TS}_{\mathrm{ow}}$ were higher in the treated samples than in the control samples. This appears to contradict the results of other authors (Jalaludin et al. 2010) who indicated that OHT wood exhibited a marked reduction in equilibrium moisture content. This discrepancy is explained because $\mathrm{TS}_{\mathrm{ow}}$ includes both water and the oil absorbed in the treatment, so PS must be used when comparing only water contents. Another aspect that can be seen in Figure 2 is that the changes in TS between the $65 \%$ SEC and $85 \%$ SEC were always lower in the treated samples than in the control samples, both in adsorption and in desorption. This indicates a more mitigated exchange of moisture content in the treated than in the control samples. This result coincides with Bak and Nemeth (2012), who indicated that moisture uptake is not blocked in OHT samples but merely decreases. The explanation may be due to crosslinking caused by the polycondensation reactions in lignin and to diminishing amounts of water-affinity hydroxyl groups owing to the heat during the treatment and the crystallisation of the cellulose (Lee et al. 2018).

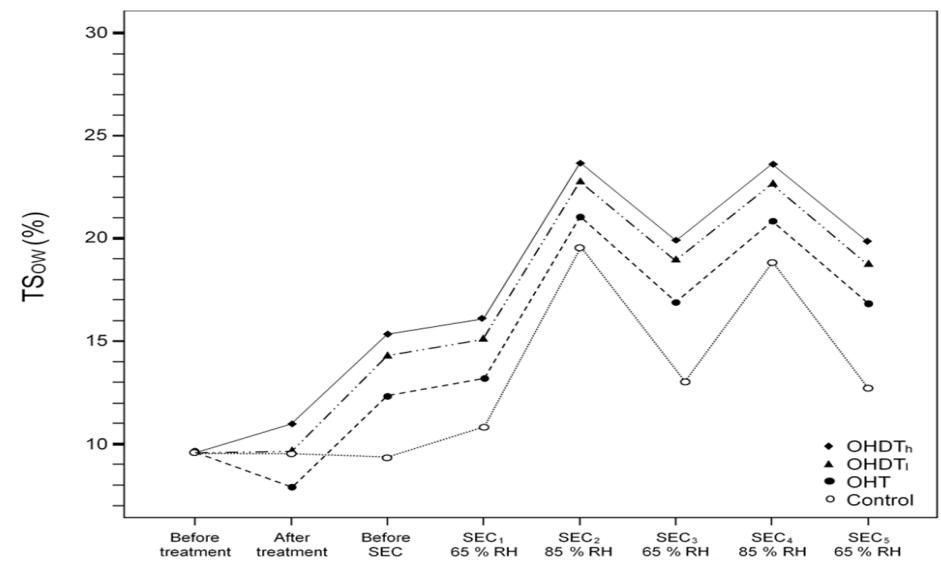

Figure 2: TSow in each stable environmental condition (SEC), grouped by treatment type.

The changes in PS are shown in Table 2. At the end of SECs 3 to 5, the $\mathrm{PS}_{\mathrm{w}}$ values in the treated samples (approximately $3 \%$ ) were significantly lower than in the control samples (approximately $5 \%$ ). This confirms the mitigation of the moisture exchanges that were detected in the $\mathrm{TS}_{\mathrm{ow}}$. Other authors have also found lower equilibrium moistures in samples treated with hot oil (Jalaludin et al. 2010, Bak and Nemeth 2012, Lee et al. 2018). The exception was the stage that elapses after treatment and before $\mathrm{SEC}_{1}$, in which the control samples practically maintained their PS $_{w}$ constant whereas the treated samples had a significantly greater increase of approximately $4 \%$. This initial increase that occurred over six months of stable relative humidity conditions reflected a partial recovery of the hygroscopic character of the treated samples. In this initial phase no significant differences were detected in the increases in $\mathrm{PS}_{\mathrm{w}}$ between the OHDT and OHT samples.

Table 2: Values of $\mathrm{PS}_{\mathrm{w}}$ (in \%) in stable environmental conditions $\left(\mathrm{SEC}_{\mathrm{i}}\right)$. The coefficient of variation is shown between brackets (in \%).

\begin{tabular}{|c|c|c|c|c|}
\hline & $\mathrm{OHDT}_{\mathrm{h}}$ & $\mathrm{OHDT}_{1}$ & OHT & control \\
\hline Before $\mathrm{SEC}_{1}$ & $3,98^{\mathrm{b}}(6,60)$ & $4,21^{b}(7,97)$ & $4,10^{\mathrm{b}}(10,28)$ & $-0,19^{a}(41,6)$ \\
\hline After SEC $\mathrm{S}_{1} 65 \% \mathrm{RH}$ & $0,66^{\mathrm{c}}(6,44)$ & $0,69^{\mathrm{c}}(7,28)$ & $0,75^{\mathrm{b}}(2,55)$ & $1,34^{\mathrm{a}}(4,05)$ \\
\hline After $\mathrm{SEC}_{2} 85 \% \mathrm{RH}$ & $6,57^{\mathrm{c}}(4,76)$ & $6,69^{\mathrm{bc}}(3,79)$ & $6,95^{b}(3,28)$ & $7,84^{\mathrm{a}}(4,29)$ \\
\hline After $\mathrm{SEC}_{3} \quad 65 \% \mathrm{RH}$ & $-3,05^{\mathrm{c}}(5,72)$ & $-3,19^{\mathrm{bc}}(6,20)$ & $-3,41^{b}(4,29)$ & $-5,42^{\mathrm{a}}(5,31)$ \\
\hline After $\mathrm{SEC}_{4} 85 \% \mathrm{RH}$ & $3,10^{b} \quad(5,13)$ & $3,18^{b}(6,40)$ & $3,37^{b} \quad(3,74)$ & $5,09^{a}(5,52)$ \\
\hline After $\mathrm{SEC}_{5} 65 \% \mathrm{RH}$ & $-3,05^{\mathrm{c}}(4,92)$ & $-3,14^{\mathrm{bc}}(5,94)$ & $-3,31^{b}(2,89)$ & $-5,14^{\mathrm{a}}(5,53)$ \\
\hline
\end{tabular}

abc Values with a different superscript letter in the same row present significant differences between treatments. 
A marked difference in $\mathrm{PS}_{\mathrm{w}}$ can be observed between $\mathrm{SEC}_{2}$ and $\mathrm{SEC}_{4}$ (with the same $85 \% \mathrm{RH}$ in both cases). This is because $\mathrm{SEC}_{2}$ comes from an environment of $65 \% \mathrm{RH}$ obtained by adsorption, and SEC4 comes from an environment of $65 \% \mathrm{RH}$ obtained by desorption. This difference is explained by sorption hysteresis (Forest Products Laboratory 2010).Within the SECs, the OHT samples presented significantly higher PS then the $\mathrm{OHDT}_{\mathrm{h}}$ samples, with some exceptions. The OHDT 1 samples with intermediate densification also had intermediate values. The moisture absorption was significantly lower in the samples that had been more densified.

The CS values are shown in Figure 3 and Figure 4. It can be seen that the OHT treatment (hot oil without densification) produced a $1 \%$ shrinkage in thickness (Figure 3) due to the replacement of water by oil. The difference in thicknesses with regard to the control samples decreased to $0,4 \%$ in the period prior to the SECs and remained more or less constant in all the SECs. The results showed some CS in the OHT samples which reached $-0,7 \%$ (equivalent to an increase in swelling of $0,7 \%$ ). The CS of the control samples were greater and reached $-1,2 \%$, a less favourable value as it is farther from $0 \%$. In all SECs the control samples presented a CS of approximately double the one obtained in OHT samples. The decreases in shrinkage in the samples treated with hot oil coincided with the results of Dubey et al. (2012a) who detected improvements in the volumetric swelling percentage in samples of Pinus radiata treated with linseed oil. Several authors have also reported improvements in anti-swelling efficiency in samples treated with OHT (Rapp 2001, Dubey et al. 2012a, Bak and Nemeth 2012). Fang et al. (2011) reported the extreme case in which the compression recovery of aspen wood veneers was eliminated with OHT treatment. This could be explained by the thinness of this type of samples.

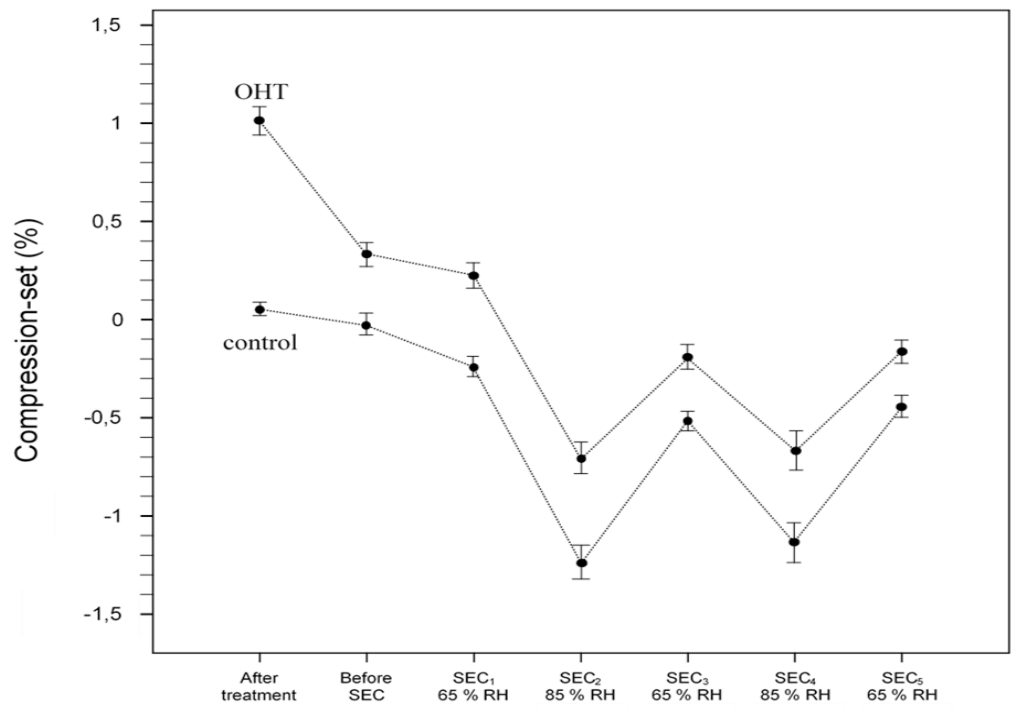

Figure 3: Compression-set of the OHT samples and control in each stage in each stable environmental condition (SEC).

The CS values in the densified samples (Figure 4) were higher than those obtained in the OHT and control samples due to densification. The initial CS obtained with densification, $30 \%$ in the $\mathrm{OHDT}_{\mathrm{h}}$ samples and 15

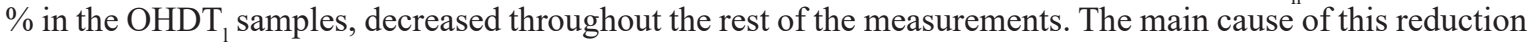
is springback, which occurred in the initial phase at a relative humidity of $65 \%$ (first springback) and in the phase of high relative humidity at $85 \%$ (second springback). 


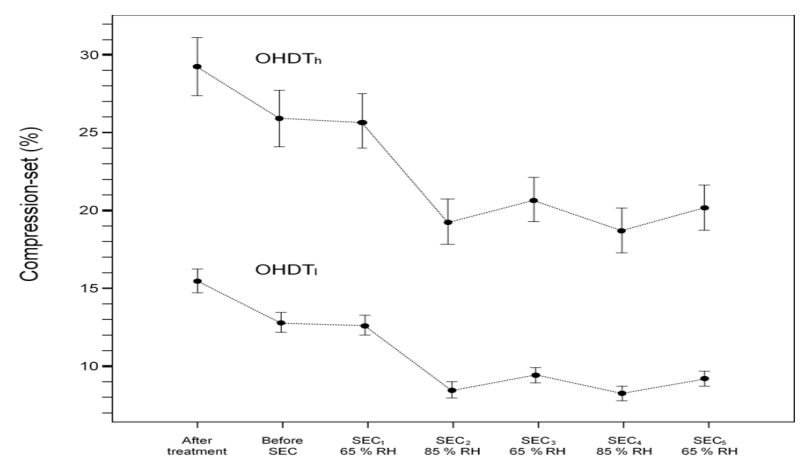

Figure 4: Compression-set of the OHDT samples in each stable environmental condition (SEC).

The first springback can be seen in the step between after treatment and $\mathrm{SEC}_{1}$ which led to a 3,3\% loss

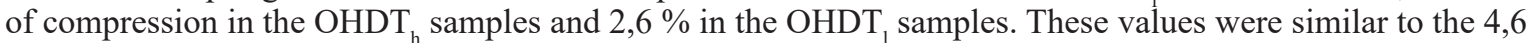
$\%$ and $1,7 \%$ found by Dubey et al. (2016) in densified samples of Pinus radiata subsequently treated with oil at $180^{\circ} \mathrm{C}$ and $210{ }^{\circ} \mathrm{C}$. The second springback presented higher values of 5,0 \% in $\mathrm{OHDT}_{\mathrm{h}}$ samples and 3,1 $\%$ in $\mathrm{OHDT}_{1}$ samples. These correspond to the step between $\mathrm{SEC}_{1}$ and $\mathrm{SEC}_{3}$ : the two first SECs with $65 \%$ relative humidity, separated by a SEC with $85 \%$, although part of this decrease was due to the fact that $\mathrm{SEC}_{1}$ was caused by adsortion and $\mathrm{SEC}_{3}$ was due to desorption, which could explain only a small part of the change. Kamke (2006) also found that the swelling of the densified wood occurred with greater intensity when the samples were submitted to high moisture content (second springback).

The presence of springback in the results of the present study coincides with the works of Navi and Girardet (2005) who observed that part of the densification is lost if the wood is re-wetted. As in the control and OHT samples, from the equilibrium in $\mathrm{SEC}_{2}$ at $85 \% \mathrm{RH}$, the changes in CS between the remaining SEC remained constant, indicating that springback had already totally occurred. The rate of swelling that occurred between environments of $65 \% \mathrm{RH}$ and $85 \% \mathrm{RH}$ differed depending on the treatment. The control samples had an oscillation in CS of $0,7 \%$, which was reduced to $0,5 \%$ in the OHT samples. In the case of the densified samples, the oscillations rose to 1,6\%, and $1 \%$ for $\mathrm{OHDT}_{\mathrm{h}}$ and $\mathrm{OHDT}_{1}$ respectively. Spear and Walker (2006) also observed an increase in shinkrage in the densified samples, which they attributed to the increased ratio of cell wall mass to lumen volume. To verify this hypothesis, the CS values were compared in each SEC for the four treatments. No significant differences were detected between the CS of the control samples and the OHT samples in any of the five SECs. In contrast, the CS values in the densified samples were significantly greater than the control samples in the $\mathrm{OHDT}_{1}$ samples, and even greater in the $\mathrm{OHDT}_{\mathrm{h}}$ samples.

Table 3: Regression slope between the age of the oil (in minutes from previous treatments) and CS (in \%).

\begin{tabular}{|c|c|c|c|}
\hline & OHDT $_{\mathrm{h}}$ & OHDT $_{1}$ & OHT \\
\hline Before SEC & $-2,34 \times 10^{-3}$ & $-1,2 \times 10^{-4} \mathrm{~ns}$ & $-3,1 \times 10^{-5} \mathrm{~ns}$ \\
\hline SEC $_{1} 65 \% \mathrm{RH}$ & $-2,35 \times 10^{-3} *$ & $-1,1 \times 10^{-4} \mathrm{~ns}$ & $-2,8 \times 10^{-5} \mathrm{~ns}$ \\
\hline $\mathrm{SEC}_{2} 85 \% \mathrm{RH}$ & $-2,02 \times 10^{-3}{ }^{* *}$ & $-3,0 \times 10^{-4} \mathrm{~ns}$ & $-6,8 \times 10^{-5} \mathrm{~ns}$ \\
\hline $\mathrm{SEC}_{3} 65 \% \mathrm{RH}$ & $-2,01 \times 10^{-3} * *$ & $-3,0 \times 10^{-4} \mathrm{~ns}$ & $-2,7 \times 10^{-5} \mathrm{~ns}$ \\
\hline $\mathrm{SEC}_{4} 85 \% \mathrm{RH}$ & $-2,01 \times 10^{-3}{ }^{* *}$ & $-3,0 \times 10^{-4} \mathrm{~ns}$ & $-2,0 \times 10^{-5} \mathrm{~ns}$ \\
\hline SEC $_{5} 65 \% \mathrm{RH}$ & $-2,10 \times 10^{-3}$ & $-2,6 \times 10^{-4} \mathrm{~ns}$ & $-4,1 \times 10^{-5} \mathrm{~ns}$ \\
\hline
\end{tabular}

The influence of the age of the oil on CS can be seen in Table 3. Significant effects were only detected in the $\mathrm{OHDT}_{\mathrm{h}}$ samples. The negative value of the slope indicates that as the oil ageds, the capacity to maintain the densification decreaseds. This decrease remaineds more or less constant in all the SECs of the OHDT samples, $^{2}$ with a $0,12 \%$ decrease in CS for each hour of prior use of the oil. In the OHDT 1 and OHT samples, the decrease was merely a trend, as all the slopes were negative even though the values were not significant. Significance was only found in the most densified samples, where the CS values are higher. However, in woods without densification or with slight densification, the influence of other effects may have masked the significance of the age of the oil. Figure 5 shows an example in $\mathrm{SEC}_{5}$. Dubey et al. (2011) detected significant differences in water absorption between woods of Pinus radiata treated with fresh linseed oil and pre-heated linseed oil. However, coinciding with the results of the present work, they found no significant differences in OHT samples when 
they compared volumetric swelling.

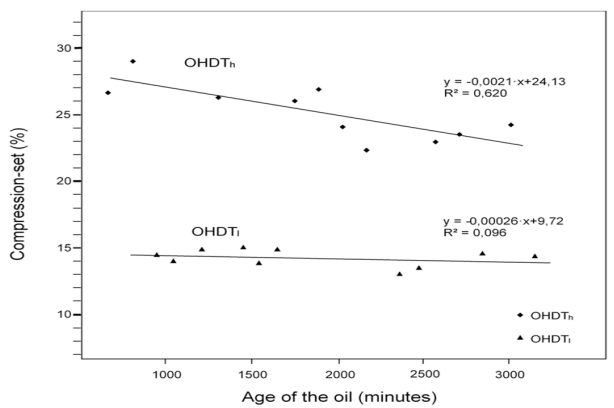

Figure 5: Relation between the age of the oil and compression-set in stable environmental condition 5

(SEC5) for the OHDTh and OHDTl samples.

\section{CONCLUSIONS}

Once the samples had stabilised at $85 \% \mathrm{RH}$, the OHDT samples presented significantly less water absorption than the untreated samples. This absorption was lower in the samples that were subjected to greater densification.

The springback in OHDT samples occurred in two ways: a first springback to constant relative humidity and a second springback when they were subjected to greater relative humidities. Once the balance had been attained at a higher relative humidity, the springback remained constant for equal or lower humidities.

In the more densified OHDT samples, the age of the oil used in the treatment had a significant influence on the loss of densification due to moisture.

The OHDT treatment made it possible to obtain the advantages produced by the densification of the wood after an OHT process, but with a single treatment. This produces an energy savings as heat only needs be to be supplied in one of the phases. The treatment time is also reduced compared to when the sequential densification process is used for the OHT treatment.

\section{REFERENCES}

AITIM. 1997. Especies de maderas para carpintería, construcción y mobiliario. Asociación de Investigación Técnica de Industrias de la Madera y Corcho (AITIM): Madrid, Spain.

Bak, M.; Nemeth, R. 2012. Modification of wood by oil heat treatment. In Proceedings of the International Scientific Conference on Sustainable Development \& Ecological Footprint. Sopron, Hungary.

Dubey, M.K.; Pang, S.; Walker, J. 2011. Effect of oil heating age on colour and dimensional stability of heat treated Pinus radiata. European Journal of Wood and Wood Products 69: 255-262. https://doi.org/10.1007/s00107-010-0431-0

Dubey, M.K.; Pang, S.; Walker, J. 2012a. Changes in chemistry, color, dimensional stability and fungal resistance of Pinus radiata D. Don wood with oil heat-treatment. Holzforschung 66(1): 49-57. https://doi.org/10.1515/HF.2011.117

Dubey, M.K.; Pang, S.; Walker, J. 2012b. Oil uptake by wood during heat-treatment and post-treatment cooling , and effects on wood dimensional stability. European Journal of Wood and Wood Products 70: 183190. https://doi.org/10.1007/s00107-011-0535-1

Dubey, M.K.; Pang, S.; Chauhan, S.; Walker, J. 2016. Dimensional stability, fungal resistance and mechanical properties of radiata pine after combined thermo-mechanical compression and oil heat-treatment. Holzforschung 70(8): 793-800. https://doi.org/10.1515/hf-2015-0174 
EN. 2002. Moisture content of a piece of sawn timber. EN 13183-1. 2002. Part 1: Determination by oven dry method. CEN: Brussels, Belgium. https://standards.cen.eu/dyn/www/f?p=204:110:0::::FSP_PROJECT,FSP_ORG_ID:7839,6156\&cs=100F48F7330BA2CCD26D59BF5D87DFAD5

Fang, C.H.; Cloutier, A.; Blanchet, P.; Koubaa, A.; Mariotti, N. 2011. Densification of wood veneers combined with oil- heat treatment. part I: dimensional stability. BioResources 6(1): 373-385. https://ojs.cnr. ncsu.edu/index.php/BioRes/article/view/BioRes_06_1_0373_Fang_CBKM_Densification_Wood_Veneers Oil_Heat

Forest Products Laboratory. 2010. Wood handbook-Wood as an engineering material. Forest Products Laboratory, Department of Agriculture: Madison, WI, USA. https://www.fpl.fs.fed.us/documnts/fplgtr/ fpl_gtr190.pdf

Fullana, A.; Carbonell-Barrachina, A.A.; Sidhu, S. 2004. Comparison of volatile aldehydes present in the cooking fumes of extra virgin olive, olive, and canola oils. J Agric Food Chem 52(16): 5207-5214. https://doi.org/10.1021/jf035241f

Gašparík, M.; Gaff, M.; Šafaříková, L.; Vallejo, C.R.; Svoboda, T. 2016. Impact bending strength and Brinell hardness of densified hardwoods. BioResources 11(4): 8638-8652. https://doi.org/10.15376/ biores.11.4.8638-8652

Hsu, W.E.; Schwald, W.; Schwald, J. 1988. Chemical and physical changes required for producing dimensionally stable wood-based composites. Wood Sci Technol 22: 281-289. https://doi.org/10.1007/BF00386023

Istok, I.; Sedlar, T.; Sefc, B.; Sinkovic, T.; Perkovic, T. 2016. Physical Properties of Wood in Poplar Clones 'I-214' and 'S1-8'. Drv Ind 67(2): 163-170. https://doi.org/10.5552/drind.2016.1604

Jalaludin, Z.; Hill, C.A.S.; Samsi, H.W., Husain, H.; Xie, Y. 2010. Analysis of water vapour sorption of oleo-thermal modified wood of Acacia mangium and Endospermum malaccense by a parallel exponential kinetics model and according to the Hailwood-Horrobin model. Holzforschung 64(6): 763-770. https://doi.org/10.1515/hf.2010.100

Kamke, F.A. 2006. Densified radiata pine for structural composites. Maderas-Cienc Tecnol 8(2): 83-92. https://scielo.conicyt.cl/pdf/maderas/v8n2/art02.pdf

Kawai, S.; Wang, Q.; Sasaki, H.; Tanahashi, M. 1992. Production of compressed laminated veneer lumber by steam pressing. In Proceedings of the Pacific Rim Bio-Based Composites Symposium, Rotorua, New Zealand. pp. 121-128.

Kollmann, F. 1959. Tecnología de la madera y sus aplicaciones. Vol I. Instituto Forestal de Investigaciones y Experiencias y Servicio de la Madera: Madrid, Spain.

Kollmann, F.P.; Kuenzi, E.W.; Stamm, A.J. 1975. Principles of wood science and technology. Vol. II Wood based materials. Springer-Verlag: New York-Heidelberg-Berlin.

Kutnar, A.; Kamke, F.A.; Sernek, M. 2008. The mechanical properties of densified VTC wood relevant for structural composites. Holz Roh Werkst 66: 439-446. https://doi.org/10.1007/s00107-008-0259-z

Kutnar, A.; Sernek, M. 2007. Densification of wood. Zbornik Gozdarstva in Lesarstva 82: 53-62. http://www.gozdis.si/zbgl/2007/zbgl-82-6.pdf

Laborie, M.P.G. 2006. The temperature dependence of wood relaxations: A molecular probe of the woody cell wall. In: Proceedings of the Characterization of the Cellulosic Cell Wall. Blackwell Publishing: Grand Lake, Colorado, USA. pp 87-94. https://doi.org/10.1002/9780470999714.ch7

Laskowska, A. 2020. Impact of cyclic densification on bending strength and modulus of elasticity of wood from temperate and tropical zones. BioResources 15(2): 2869-2881. https://bioresources.cnr.ncsu.edu/ wp-content/uploads/2020/03/BioRes_15_2_2869_Laskowska_Impact_Thermo_mechan_Densification_ Bending_Str_MOE_Wood_Zones_16914.pdf 
Lee, S.H.; Ashaari, Z.; Lum, W.C.; Halip, J.A.; Ang, A.F.; Tan, L.P.; Chin, K.L.; Tahir, P.M. 2018. Thermal treatment of wood using vegetable oils : A review. Constr Build Mater 181: 408-419. https://doi.org/10.1016/j.conbuildmat.2018.06.058

Li, X.; Bremer, G.C.; Connell, K.N.; Ngai, C.; Pham, Q.A.T.; Wang, S.; Flynn, M.; Ravetti, L.; Guillaume, C.; Wang, Y.; Wang, S.C. 2016. Changes in chemical compositions of olive oil under different heating temperatures similar to home cooking. Journal of Food Chemistry and Nutrition 4(1): 07-15. https://esciencepress.net/journals/index.php/JFCN/article/view/1532

Lyon, F.; Thevenon, M.F.; Hwang, W. J.; Imamura, Y.; Gril, J.; Pizzi, A. 2007. Effect of an oil heat treatment on the leachability and biological resistance of boric acid impregnated wood. Ann For Sci 64: 673678. https://doi.org/10.1051/forest:2007046

Morsing, N. 1998. Densification of wood - The influence of hygrothermal treatment on compression of beech perpendicular to the grain. Series R, N 79. Department of Structural Engineering and Materials, Technical University of Denmark: Lyngby, Denmark. https://core.ac.uk/download/pdf/13738419.pdf

Navi, P.; Girardet, F. 2005. Effects of thermo-hydro-mechanical treatment on the structure and properties of wood. Holzforschung 54(3): 287-293. https://doi.org/10.1515/HF.2000.048

Okon, K.E.; Lin, F.; Lin, X.; Chen, C.; Chen, Y.; Huang, B. 2018. Modification of chinese fir (Cunninghamia lanceolata L.) wood by silicone oil heat treatment with micro-wave pretreatment. Eur J Wood Prod 76: 221-228. https://doi.org/10.1007/s00107-017-1165-z

R Core Team. 2019. R: A language and environment for statistical computing. Version 3.6.1. R Foundation for Statistical Computing: Vienna, Austria. https://cran.r-project.org/

Rapp, A.O. 2001. Review on heat treatments of wood. In: Proceedings of the Special Seminar COST E22, Antibes, France. https://projects.bre.co.uk/ecotan/pdf/Heat_treatment_processes_Andreas_Rapp\%20.pdf

Reiterer, A.; Stanzl-Tschegg, S.E. 2001. Compressive behaviour of softwood under uniaxial loading at different orientations to the grain. Mech Mater 33(12): 705-715. https://doi.org/10.1016/S0167-6636(01)00086-2

Song, J.; Chen, C.; Zhu, S.; Zhu, M.; Dai, J.; Ray, U.; Li, Y.; Kuang, Y.; Li, Y.; Quispe, N.; Yao, Y.; Gong, A.; Leiste, U.; Bruck, H.; Zhu, J.; Vellore, A.; Li, H.; Minus, M.; Jia, Z.; Martini, A.; Li, T.; Hu, L. 2018. Processing bulk natural wood into a high-performance structural material. Nature 554: 224-228. https://doi.org/10.1038/nature25476

Sotomayor, J.R. 2016. Efecto del densificado de la madera de Gyrocarpus americanus Jacq . en su módulo dinámico determinado por ondas de esfuerzo (Effect of the densified of Gyrocarpus americanus Jacq. wood in its dynamic modulus established by stress waves). Ciencia Amazónica 6(2): 162-171. https://doi.org/10.22386/ca.v6i2.117

Spear, M.; Walker, J.C.F. 2006. Dimensional instability in timber. In: Primary Wood Processing, Principles and Practice. J.C.F, Walker (Ed). Springer: Dordrecht, Netherlands. p. 95-120. https://doi.org/10.1007/14020-4393-7 4

Tomak, E.D.; Hughes, M.; Yildiz, U.C.; Viitanen, H. 2011. The combined effects of boron and oil heat treatment on beech and Scots pine wood properties. Part 1: Boron leaching, thermogravimetric analysis, and chemical composition. J Mater Sci 46: 598-607. https://doi.org/10.1007/s10853-010-4859-8

Wang, J.Y.; Cooper, P.A. 2005. Effect of oil type, temperature and time on moisture properties of hot oil-treated wood. Holz Roh Werkst 63: 417-422. https://doi.org/10.1007/s00107-005-0033-4

Wehsener, J.; Brischke, C.; Meyer-Veltrup, L.; Hartig, J.; Haller, P. 2018. Physical, mechanical and biological properties of thermo-mechanically densified and thermally modified timber using the Vacu ${ }^{3}$-process. European Journal of Wood and Wood Products 76: 809-821. https://doi.org/10.1007/s00107-017-1278-4

Welzbacher, C.R.; Wehsener, J.; Rapp, A.O.; Haller, P. 2008. Thermo-mechanical densification combined with thermal modification of Norway spruce (Picea abies Karst) in industrial scale - Dimensional stability and durability aspects. Holz Roh Werkst 66: 39-49. https://doi.org/10.1007/s00107-007-0198-0 